\title{
Discriminação racial indireta e ação afirmativa no emprego sob a perspectiva dos direitos coletivos
}

Santiago Falluh Varella

Curso: Doutorado em Sociologia

Data da defesa: 27 março de 2009

Orientador: Prof. Dr. Sadi Dal Rosso

\section{Resumo}

A pesquisa versa sobre a primeira tentativa de reconhecimento jurídico da discriminação racial indireta no Brasil. Para tanto, analisa os documentos de cinco ações civis públicas iniciadas pelo Ministério Público do Trabalho contra as filiais dos maiores bancos privados brasileiros no Distrito Federal. Tais ações propuseram que o Judiciário reconhecesse a discriminação indireta e referendasse ações afirmativas para reparar prejuízos causados aos interesses da coletividade dos negros do Distrito Federal. A pesquisa se concentra nas resistências tanto em identificar a discriminação quanto em adotar políticas para o seu combate. Para explicar as oposições do primeiro tipo são analisadas ideologias sobre o Brasil como um país de igualdade racial, idealizações que reduzem o racismo às suas manifestações individuais ou que o atribuem a outras causas. Para explicar as do segundo tipo, são analisados argumentos receosos das consequências sociais negativas das políticas afirmativas, quer para a harmonia racial, quer para a ordem econômica capitalista, quer para as tradições do próprio Poder Judiciário. 
Antes de testar em que medida cada um desses fatores determinou as posturas opostas às ações afirmativas, analisa-se a consistência do argumento central alegado para não referendar ações afirmativas: faltam provas da discriminação racial. Além das inconsistências desses argumentos, demonstra-se que as dificuldades de identificação da discriminação relacionaram-se com estratégias de isenção das responsabilidades pela sua reparação. As visões sobre as causas da discriminação racial levaram a conclusões pela impossibilidade de repará-la, pois o status social subalterno dos negros relacionar-se-ia apenas à sua própria incapacidade individual, fruto da herança histórica, ou seria resultado da incapacidade do Estado em prover soluções universais. Não só as suas causas são tidas como complexas demais para que ações afirmativas sejam adotadas, mas os efeitos dessas políticas seriam negativos porque aumentariam o estigma negativo sobre os negros e acirrariam os conflitos inter-raciais. Isso seria negativo para a sociedade, que passaria a funcionar pela lógica do privilégio, e não mais do mérito individual. E seria negativo para o Judiciário, que não poderia se pautar por lógicas de preferência no caso dos negros porque não existem leis que referendam tal postura.

Conclui-se que ideologias e interesses articularam-se tanto para isentar a elite econômica por ônus incidentes sobre ela em maior monta, quanto como estratégia da elite jurídica de manter tradições republicanas de matriz liberal, evitando aplicar as regras típicas do processo coletivo.

Palavras-chave: poder judiciário; direitos coletivos; discriminação racial; ação afirmativa. 